\title{
USE OF SELECTED PREDICTION EQUATIONS (CG, MDRD4, CKD-EPI) IN IMPROVING GLOMERULAR FILTRATION RATE ASSESSMENT IN CLINICAL PRACTICE IN SLOVAKIA
}

\author{
Tomáš Žatko ${ }^{1}$, Branislav Kolenaa ${ }^{1}$, Ida Petrovičová ${ }^{1}$, Tomáš Pilka ${ }^{1}$, Anton Kolačan ${ }^{2}$ \\ ${ }^{1}$ Department of Zoology and Anthropology, Constantine the Philosopher University in Nitra, Nitra, Slovakia \\ ${ }^{2}$ Department of Clinical Biochemistry, Hospital in Partizánske, Partizánske, Slovakia
}

\begin{abstract}
SUMMARY
Our study aimed to establish the best prediction equation for different age ranges in estimating Glomerular Filtration Rate (GFR) in clinical practice in Slovakia. The GFR by 24-hour creatinine clearance $\left(\mathrm{C}_{\mathrm{cr}}\right)$ and the estimated GFR (eGFR) using the Cockcroft-Gault (CG), the four-variable Modification of Diet in Renal Disease (MDRD4) and the Chronic Kidney Disease Epidemiology Collaboration (CKD-EPI) equations were obtained in adults aged 30-80 ( $n=433,10$-years intervals). The correlation between these prediction equations and $C_{c r}$ was evaluated. Errors in prediction equations were detected by moving average and by comparisons of the formulas for GFR $<1.5 \mathrm{ml} / \mathrm{s}$ and $>1.5 \mathrm{~m} / \mathrm{s}$. The best correlations were established between $C_{c r}$ and MDRD4 for women $(r=0.7790)$ and men $(r=0.8009)$, and between $C_{c r}$ and CKD-EPI for women $(r=0.7780)$ and men $(r=0.8002)$ in the 60-69 age range. High correlation was also established between $C_{c r}$ and $C G(r=0.8655)$ and MDRD4 $(r=0.8713)$ for men in the 40-49 age range. With the exception of the 30-40 age range, a low prediction error was observed for each age range in both genders when GFR was $<1.5 \mathrm{ml} / \mathrm{s}$. We recommend utilization of the MDRD4 and CG equations for men (40-49 years) and MDRD4 and CKD-EPI for women and men (60-69 years), as preferred substitutes for $C_{c r}$.
\end{abstract}

Key words: glomerular filtration rate, Cockroft-Gault equation, MDRD 4 equation, CKD-EPI equation, creatinine clearance

Address for correspondence: T. Žatko, Department of Zoology and Anthropology, Constantine the Philosopher University, Nábrežie mládeže 91, 94974 Nitra, Slovakia. E-mail: zatko.szsfuturum@gmail.com

\section{INTRODUCTION}

According to statistics from the US and others countries, the number of patients diagnosed with kidney disease doubled between 2003 and 2010, and the latest Slovak Nephrological Society statistics recorded a rising trend in the incidence of chronic kidney disease. The serious consequences emanating from this condition significantly affect patients' quality of life and ultimately their mortality rate. Although glomerular filtration rate (GFR) is considered the best overall index of kidney function in health and disease, precise GFR measurement is invasive, time-consuming, expensive and technically difficult (1-4). GFR is estimated by clearance of the inulin, iohexol and ethylenediaminetetraacetic acid (EDTA) exogenous markers and by endogenous urea and creatine (5-7). The most commonly used method to evaluate GFR is by creatinine clearance $\left(\mathrm{C}_{\mathrm{cr}}\right)$, where its rate is established by the amount of creatine completely cleared by the kidneys in 1 minute. Creatinine is a product of muscle creatine metabolism, and since it is filtered by the kidneys and not reabsorbed by renal tubules, it is ideal for determining GFR (8).

Serum creatinine concentration is a reflection of the glomerular filtration rate, and since its measurement is easily obtained and relatively inexpensive, this determination is often used as a screening measure of renal function and $\mathrm{C}_{\mathrm{cr}}$ is commonly used in clinical medicine to assess GFR (9). Creatinine production from muscle creatine decreases with increasing age and loss of muscle mass, thus, serum creatinine can be deceptively low despite significant reduction in $\mathrm{C}_{\mathrm{cr}}$. Hence $\mathrm{C}_{\mathrm{cr}}$ is considered a better indicator of renal function than the serum creatinine level (10). Problems in measuring $\mathrm{C}_{\mathrm{cr}}$ primarily emanate from 24 hour urine collection, which can initiate gross errors in $\mathrm{C}_{\mathrm{cr}}$ determination due to subjective or objective mechanisms. Herein, prediction equations determining $\mathrm{C}_{\mathrm{cr}}$ and GFR based on the determination of serum concentrations of creatinine $\left(\mathrm{S}_{\mathrm{cr}}\right)$ and extrarenal factors including age, weight, gender, and ethnicity, are utilized to resolve problems connected with unreliable urine collection (11). Cockroft and Gault (CG) and the Modification of Diet in Renal Disease equation (MRDR) developed in a multi-centre American study present the most widely used prediction equations for determination of $\mathrm{C}_{\mathrm{cr}}$ and GFR $(12,13)$.

In addition, the new Chronic Kidney disease Epidemiology Collaboration equation (CKD-EPI) has been developed for the GFR estimation by the National Institutes of Diabetes, Digestive and Kidney Disease (3). This study focuses on the comparison of $\mathrm{C}_{\mathrm{cr}}$ and prediction equations to assess the relative competence of the CG, MDRD4 and CKD-EPI formulas for differently aged patients in Slovakia, where the use of eGFR is not a common practice. 


\section{MATERIALS AND METHODS}

\section{Cohort Analysis and Sample Collection}

The Cohort comprised 433 adults; 151 men (35\%) and 282 women (65\%) from the Haemodialysis Centre of the Partizánske Hospital in Slovakia. Participants were divided into the following age groups: $30-39$ years (19 women and 10 men), 40-49 years (27 women and 20 men), 50-59 years (65 women and 40 men), 60-69 years ( 77 women and 45 men), and 70-79 years (94 women and 36 men). Patients with hypertension, diabetes and diagnosed renal disease were excluded from this study.

Serum samples from 24-hour urine collection by participants were evaluated by medical staff under specific laboratory conditions.

\section{Creatinine Clearance $\left(\mathrm{C}_{\mathrm{cr}}\right)$}

Creatinine measurement in urine and blood samples was detected by a non-enzymatic method using CREAT KIN 100 (Pliva-Lachema a.s., Czech republic). $\mathrm{C}_{\mathrm{cr}}$ determination was provided by the Selectra XL fully automatic analyzer, and GFR based on plasma creatinine concentration was calculated using the following three formulas:

1. The CG formula:

GFRCG $=\left\{[(140-\right.$ age/years $/) \times$ weight $\left./ \mathrm{kg} /] /\left[72 \times \mathrm{S}_{\mathrm{cr}} / \mu \mathrm{mol} / / / /\right]\right\} \times$ (0.85 for women)

2. The MDRD4 formula:

GFRMDRD4 $=175 \times \mathrm{S}_{\mathrm{cr}} / \mu \mathrm{mol} / \mathrm{l} /^{-1.154} \times$ age/years $/^{-0.203} \times 1.212$ (for black people) $\times 0.742$ (for women)

3. The CKD-EPI formula:

$\mathrm{GFR}_{\text {CKD-EPI }}=141 \times \min \left(\mathrm{S}_{\mathrm{cr}} \mathrm{k}, 1\right)^{\mathrm{a}} \times \max \left(\mathrm{S}_{\mathrm{cr}} \mathrm{k}, 1\right)^{-1.209} \times 0.993^{\text {Age }}$ $\times 1.018$ (for women) $\times 1.159$ (for black people)

$\mathrm{S}_{\mathrm{cr}}$ is serum creatinine $[\mu \mathrm{mol} / \mathrm{l}]$

$\mathrm{k}$ is 0.7 for women and 0.9 for men

$\mathrm{a}$ is -0.329 for women and -0.411 for men

min. indicates the minimum of $\mathrm{S}_{\mathrm{cr}} / \mathrm{k}$ or 1

max. indicates the maximum of $\mathrm{S}_{\mathrm{Cr}} / \mathrm{k}$ or 1

Estimation of GFR was established by the NKF's Calculators for Health Care Professionals using the MDRD4, CKD-EPI and CG prediction formulae.

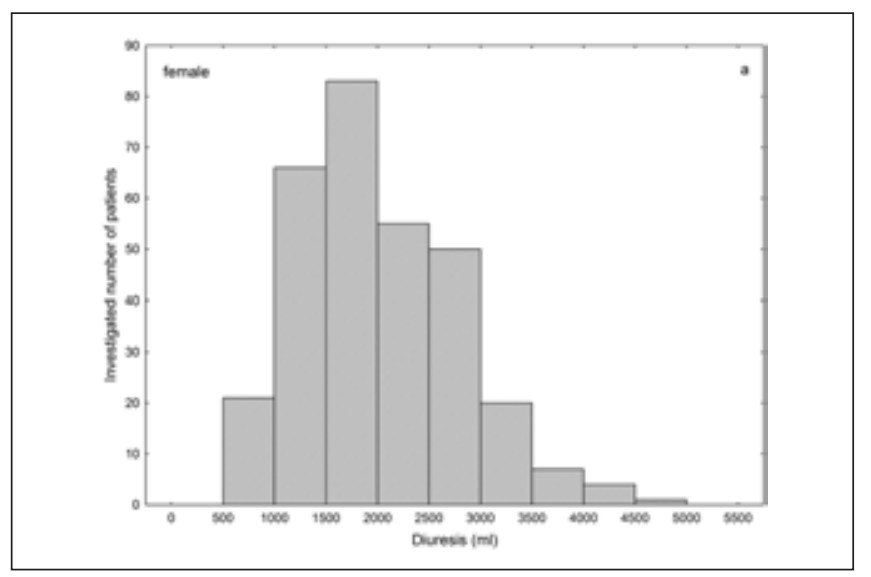

Fig. 1. Diuresis of investigated patients; women and men

\section{Statistical Analysis}

Initial correlation was established between prediction equations CG, MDRD4, CKD-EPI and $\mathrm{C}_{\mathrm{cr}}$.

Statistical significance between prediction equations and $\mathrm{C}_{\mathrm{cr}}$ was evaluated by Pearson's Correlation Coefficient, where correlations were divided into the following three intervals: low degree of correlation ( $\mathrm{r}=0-0.25)$, moderate degree of correlation $(r=0.25-0.75)$ and high degree of correlation $(r=0.75-1.0)$. Standard deviations between prediction equations CG, MDRD4, CKD-EPI and $\mathrm{C}_{\mathrm{cr}}$ were computed, and the values for the standard deviations of equations overlying with moving average were extrapolated in charts.

For the purpose of this study, the cohort was divided into two groups: GFR $<1.5 \mathrm{ml} / \mathrm{s}$ (patients with chronic kidney disease by NKF) and GFR $>1.5 \mathrm{ml} / \mathrm{s}$ (patient with normal or increased GFR). The studied groups were tested for statistical consistency of errors in the CG, MDRD4 a CKD-EPI prediction equations.

Verification of the results between studied groups was evaluated by average and S.E.M. at three significance levels; ${ }^{*} \mathrm{p} \leq 0.05$ $(5 \%),{ }^{*} \mathrm{p} \leq 0.01(1 \%)$ and $* * * \mathrm{p} \leq 0.001(0.1 \%)$, and analyses were computed using Statistica 7 (Statsoft, Czech Republic).

\section{RESULTS}

\section{Diuresis Assessment}

Serum creatinine values were available from 457 individuals. In order to eliminate inaccuracies in 24-h urine collection, subjects with urine volumes $<0.6 \mathrm{l}$ and $>5 \mathrm{l}$, and urinary creatinine $<4$ or $>25 \mathrm{mmol} /$ day were excluded. Characteristics of the cohort are detailed in the Methods section. The diuretic examination results did not provide a smooth distribution of values, with some sharp limits noted (Fig. 1) The commonly required measurements to the nearest $10 \mathrm{ml}$ were present only in small numbers; with the most common diuresis reported to the nearest litre, half litre or $100 \mathrm{ml}$. Surprisingly, diuresis between 1,000-2,000 ml for women and 1,500-2,500 for men was detected in 50\% of examined patients. This effect was most likely due to patient error; delivering estimates rather than accurate measurements. Such complications affected the accuracy of creatinine clearance in a classical manner.

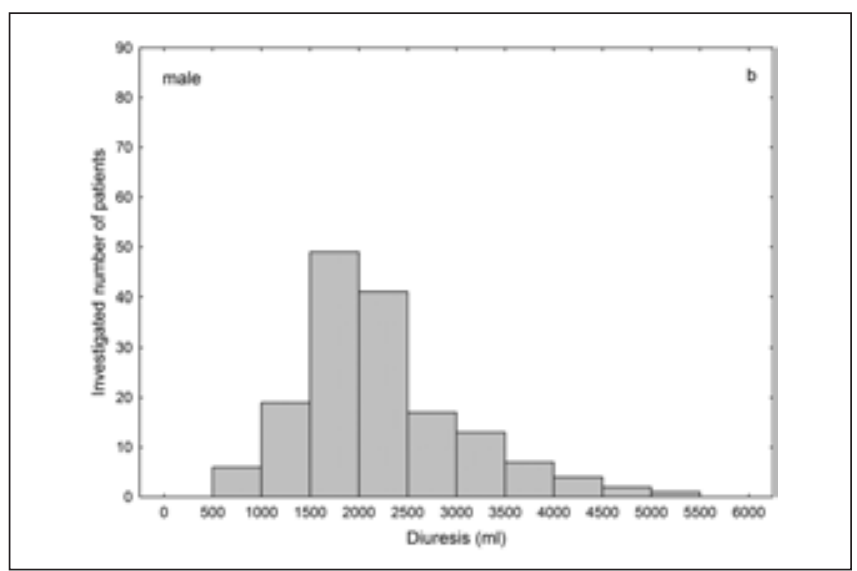




\section{Correlation Analysis of Prediction Equations with $\mathrm{C}_{\mathrm{cr}}$ Moving Average of Errors of Prediction Equations and Comparison of Prediction Equation in the Interval GFR $>1.5$ and $<$ GFR}

The results of statistical analysis in 10-year age-group intervals are given in Fig. 2.

\section{The 30-39 year age group}

Women

Correlation analysis of prediction equations with $\mathrm{C}_{\mathrm{cr}}$ gave a low degree of correlation between $C G$ and $\mathrm{C}_{\mathrm{cr}}(\mathrm{r}=0.1050)$, while the MDRD4 formula ( $r=0.3390)$ and CKD-EPI formula $(r=0.3420)$ delivered a moderate degree of correlation. The moving average suggested varying tendency of prediction equation error. Although it increased when $\mathrm{C}_{\mathrm{cr}}$ was above $2.1 \mathrm{ml} / \mathrm{s}$; no significant differences between prediction equations and $\mathrm{C}_{\mathrm{cr}}$ were identified when $\mathrm{C}_{\mathrm{cr}}$ was above or below $1.5 \mathrm{ml} / \mathrm{s}$.

Men

A moderate degree of correlation was established between all prediction equations and $\mathrm{C}_{\mathrm{cr}}$, with $\mathrm{r}=0.6233$ for MDRD4, $r=0.6142$ for CKD-EPI and $r=0.3512$ for CG. Although the moving average suggested by prediction equation error also had a varying tendency; no significant difference between prediction equations was found, when $\mathrm{C}_{\mathrm{cr}}$ was above or below $1.5 \mathrm{ml} / \mathrm{s}$.
The 40-49 year age group

Women

Correlation analysis of prediction equations with $\mathrm{C}_{\mathrm{cr}}$ show a moderate degrees of correlation with MDRD4 $(\mathrm{r}=0.5910)$, CG $(r=0.5750)$ and CKD-EPI $(r=0.5520)$. The moving average suggested by prediction equation error tended to increase with increasing $\mathrm{C}_{\mathrm{cr}}$. Significant differences were established for prediction equation error for CG (GFR $<1.5 \mathrm{ml} / \mathrm{s}$ and $>1.5 \mathrm{ml} / \mathrm{s}$, $\mathrm{p}=0.05)$, MDRD4 (GFR $<1.5 \mathrm{ml} / \mathrm{s}$ and $>1.5 \mathrm{ml} / \mathrm{s}, \mathrm{p}=0.01)$ and CKD-EPI (GFR $<1.5 \mathrm{ml} / \mathrm{s}$ and $>1.5 \mathrm{ml} / \mathrm{s}, \mathrm{p}=0.05)$.

Men

Correlation analysis of prediction equations with $\mathrm{C}_{\mathrm{cr}}$ revealed a high degree of correlation between MDRD4 $(r=0.8713)$ and CG ( $r=0.8655)$, while the CKD-EPI formula exhibited a moderate degree of correlation $(r=0.3512)$. The prediction equation error was lower when $\mathrm{C}_{\mathrm{cr}}<1.5 \mathrm{ml} / \mathrm{s}$, but it had an intensive increase when $\mathrm{C}_{\mathrm{cr}}>1.5 \mathrm{ml} / \mathrm{s}$. Significant differences were established for prediction equation error for CG (GFR $<1.5 \mathrm{ml} / \mathrm{s}$ and $>1.5 \mathrm{ml} / \mathrm{s}, \mathrm{p}=0.01)$, MDRD4 (GFR $<1.5 \mathrm{ml} / \mathrm{s}$ and $>1.5 \mathrm{ml} / \mathrm{s}, \mathrm{p}=0.001)$ and CKD-EPI $(\mathrm{GFR}<1.5 \mathrm{ml} / \mathrm{s}$ and $>1.5 \mathrm{ml} / \mathrm{s}, \mathrm{p}=0.001$ ).

The interval 30-39 years:

Women
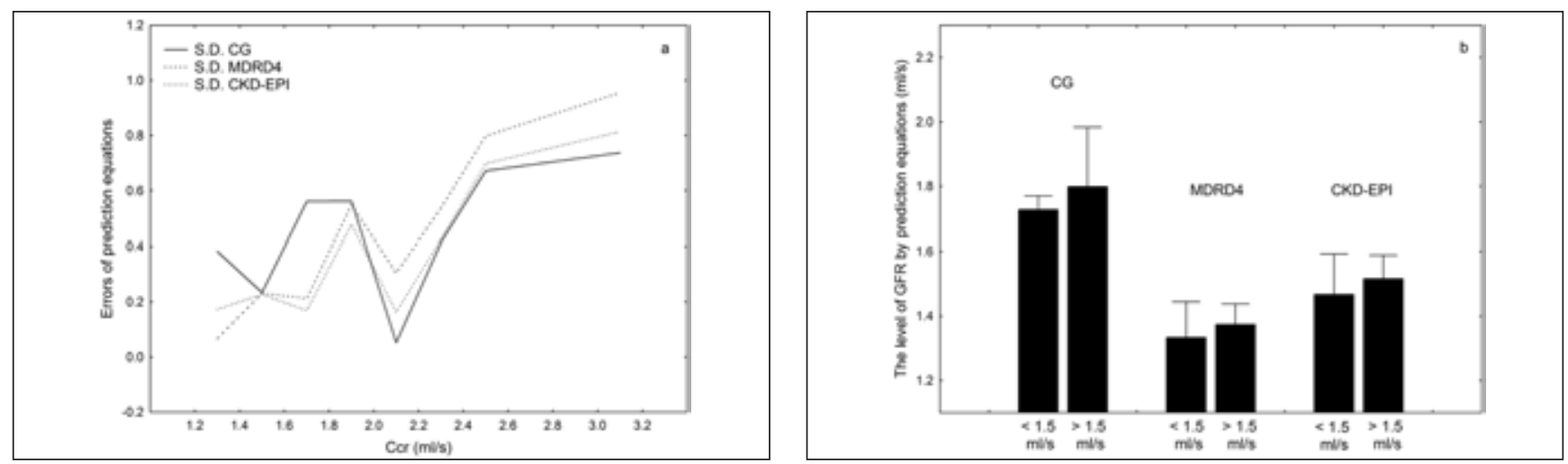

Men
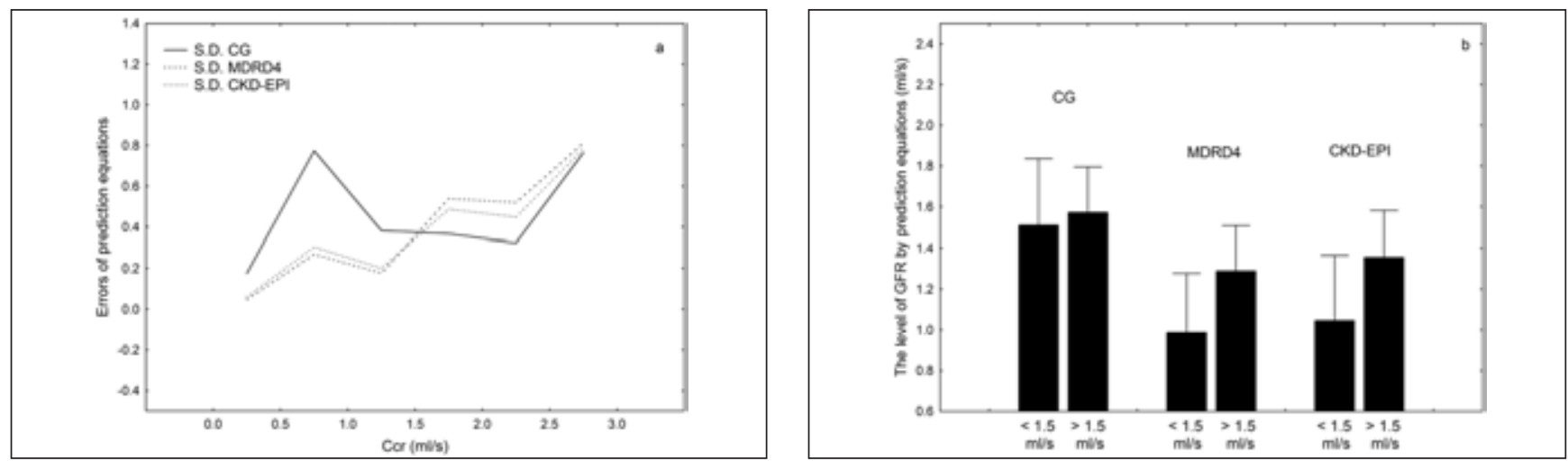

Fig. 2 a) Errors in the CG, MDRD4 and CKD-EPI prediction equations. The moving average of the absolute value of S.D.M. b) Comparison of GFR calculated by using prediction equations CG, MDRD4 and CKD-EPI for GFR $<1.5 \mathrm{ml} / \mathrm{s}$ and $>1.5 \mathrm{ml} / \mathrm{s}$. Bars and error bars represent the mean \pm S.E.M; *denotes significant difference between the studied groups.

Contd. on the following pages 
The interval 40-49 years:

Women

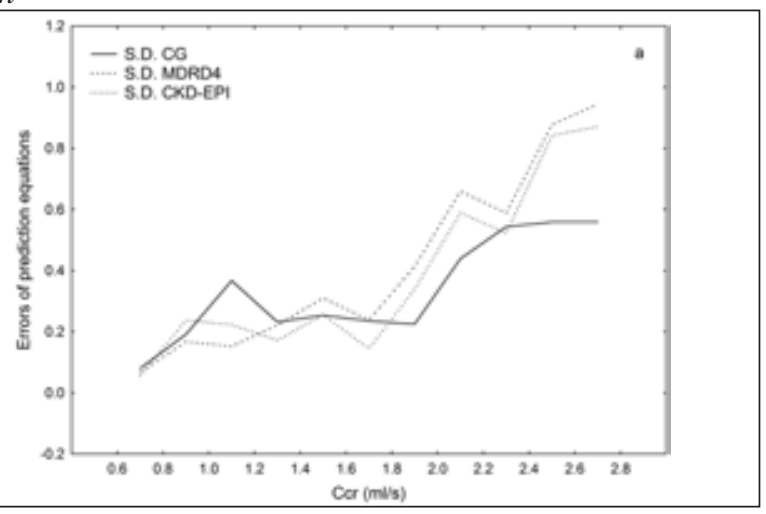

Men

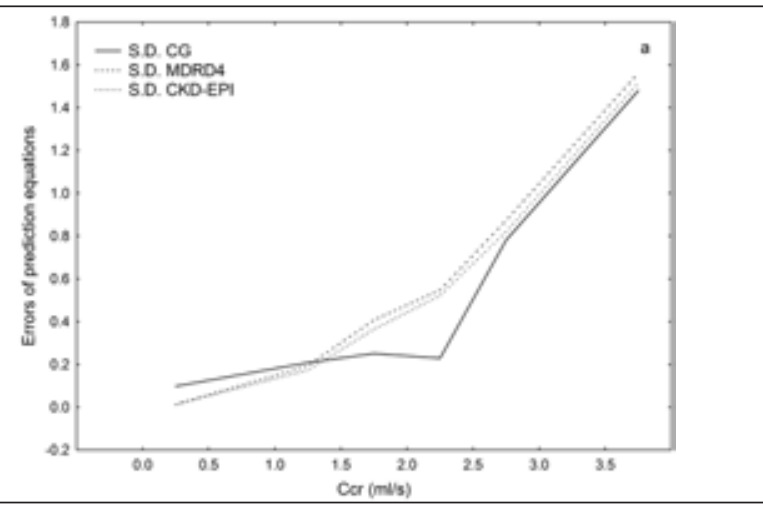

The interval 50-59 years:

\section{Women}

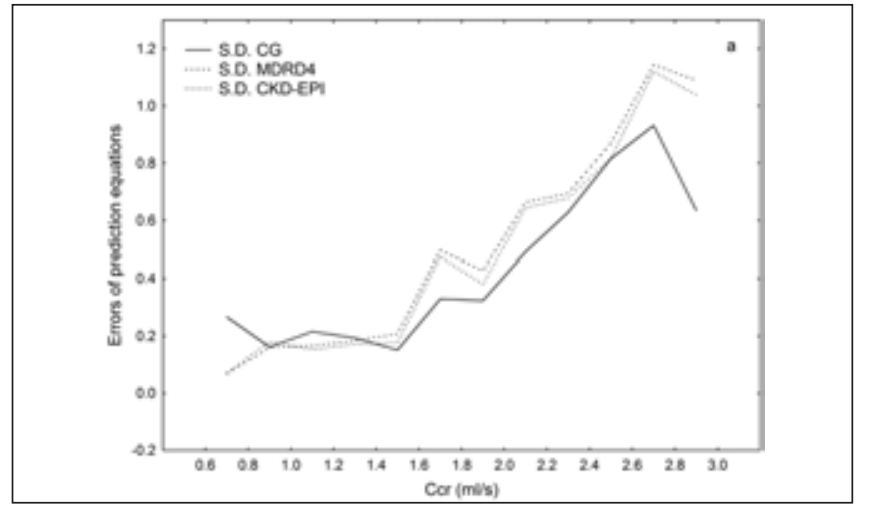

Men

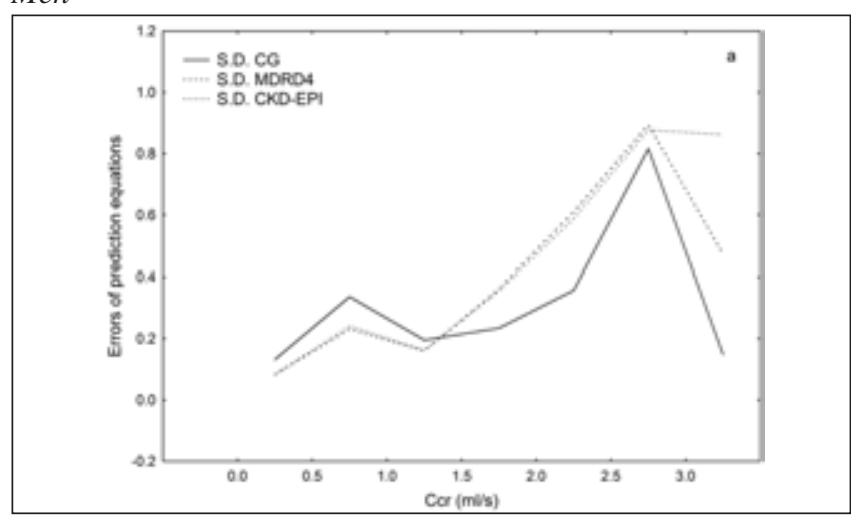

Fig. 2. (cont. from page 36)
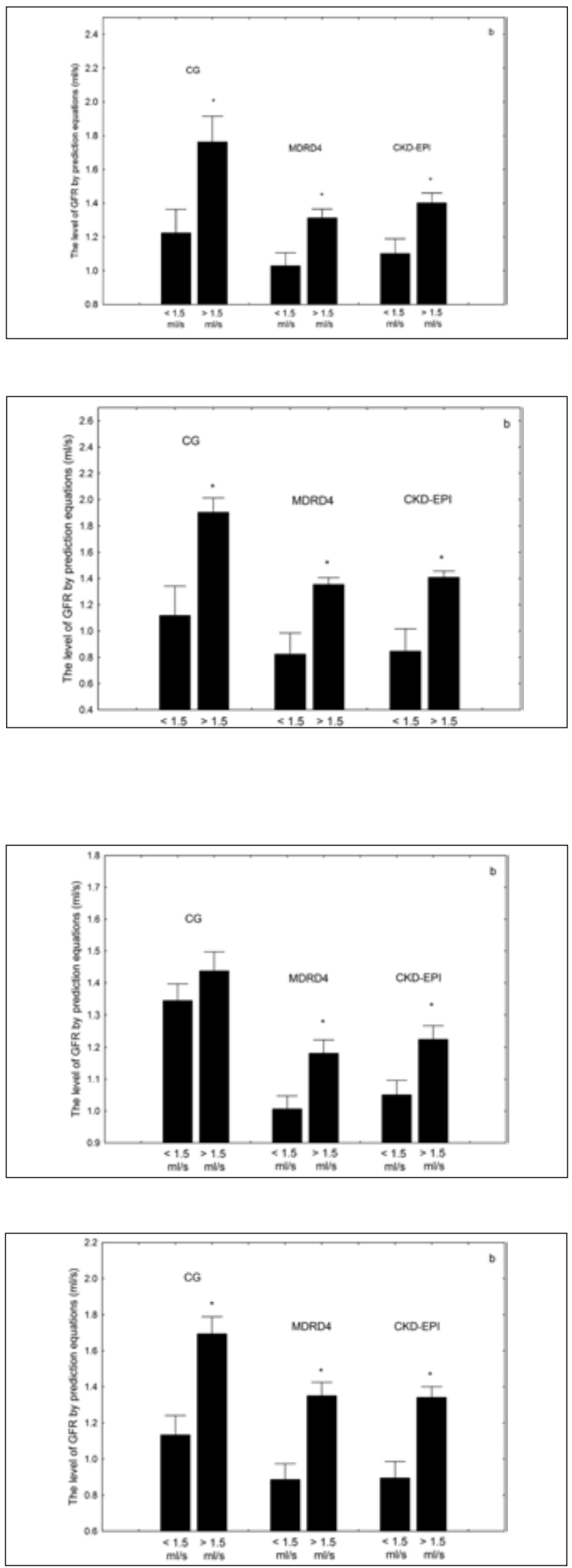
The interval 60-69 years:

Women

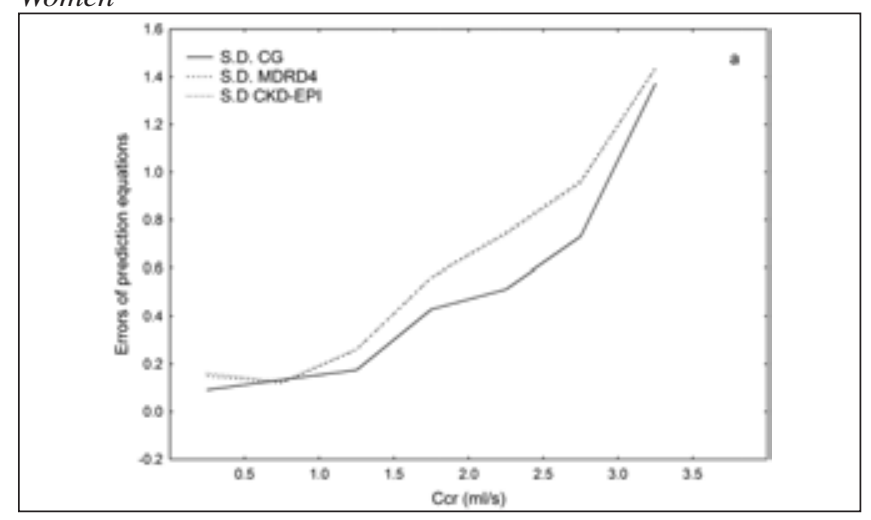

Men

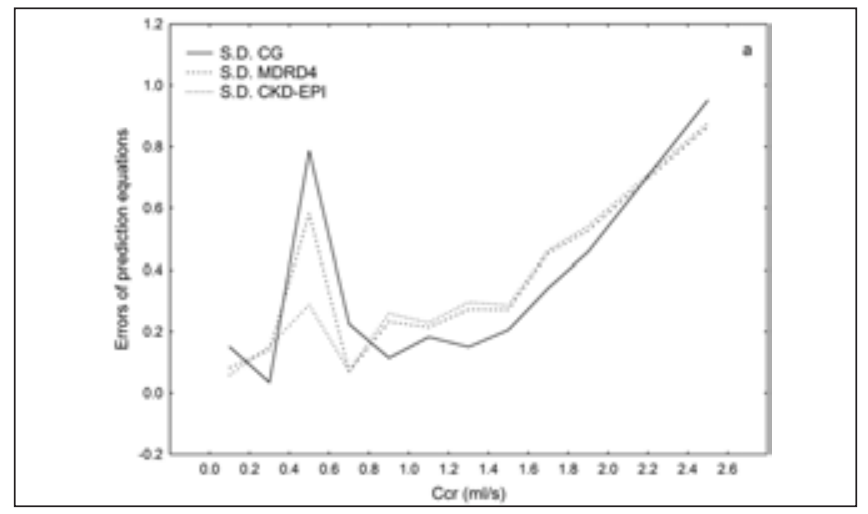

The interval 70-79 years:

Women

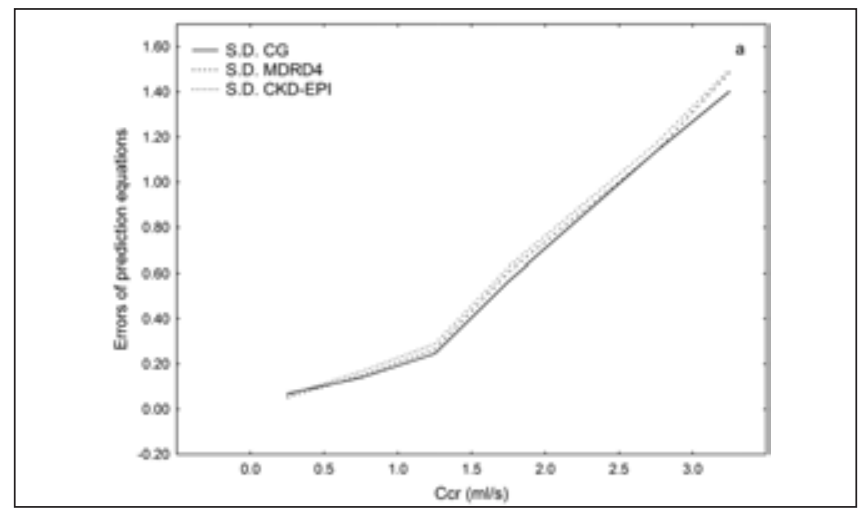

Men

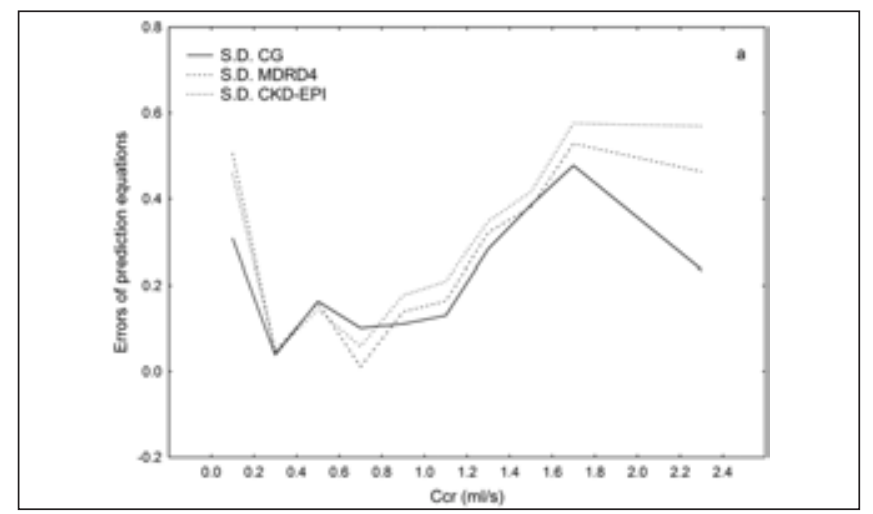

Fig. 2. (cont. from page 37)
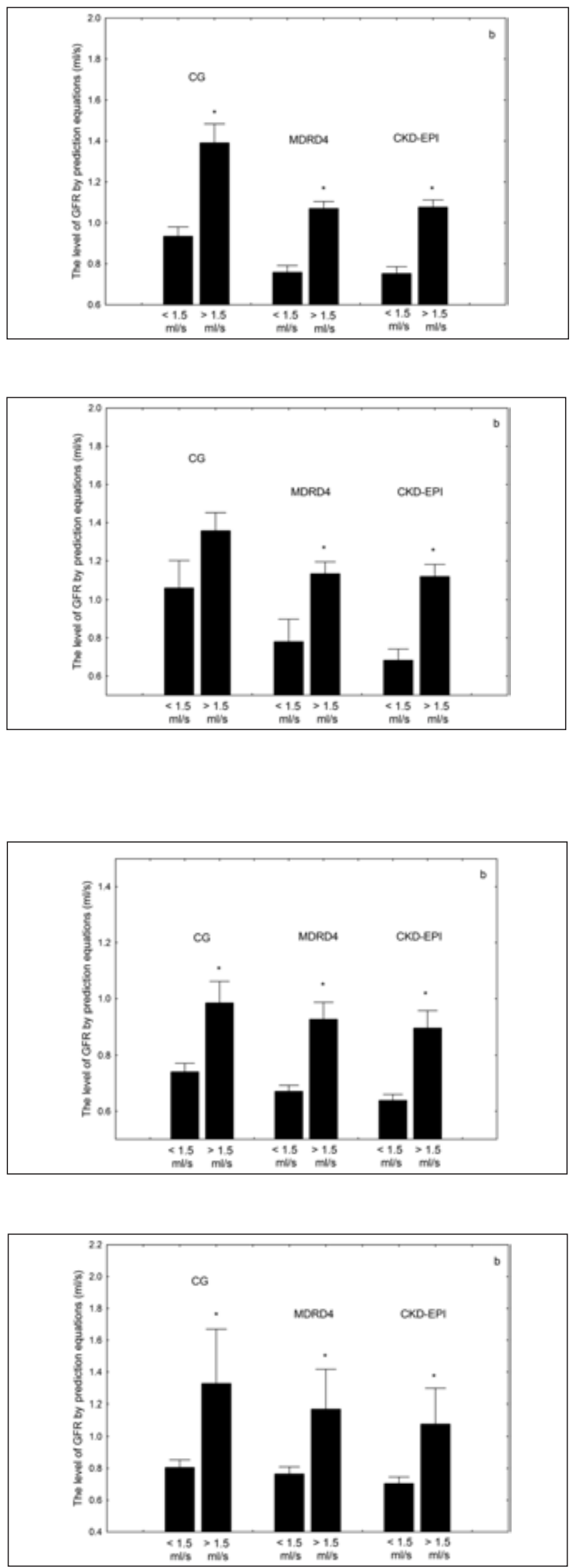
The 50-59 year age group

Women

Correlation analysis of prediction equations and $\mathrm{C}_{\mathrm{cr}}$ revealed a moderate degree of correlation in each case: (MDRD4 $r=0.5030$; CKD-EPI $-r=0.4950$; CG $-r=0.3520$ ). The moving average suggested by prediction equation error was at a low level at $1.5 \mathrm{ml} / \mathrm{s}$, but it tended to increase above this value. While significant differences were established for prediction equation error for MDRD4 (GFR $<1.5 \mathrm{ml} / \mathrm{s}$ and $>1.5 \mathrm{ml} / \mathrm{s}, \mathrm{p}=0.01$ ) and CKD-EPI (GFR $<1.5 \mathrm{ml} / \mathrm{s}$ and $>1.5 \mathrm{ml} / \mathrm{s}, \mathrm{p}=0.05)$; no significant difference was found for CG at those levels.

Men

In this group, correlation analysis detected a moderate degree of correlation between each prediction equation and $\mathrm{C}_{\mathrm{cr}}$ (MDRD4 - r=0.7366; CKD-EPI $-\mathrm{r}=0.7177$ and CG $r=0.0622$ ). The moving average had a low prediction equation error up to $1.5 \mathrm{ml} / \mathrm{s}$ and then a slightly increasing tendency. The prediction equation error for GFR over $2.5 \mathrm{ml} / \mathrm{s}$ had a sharply declining tendency. Significant differences were established for prediction equation error for CG (GFR $<1.5$ $\mathrm{ml} / \mathrm{s}$ and $>1.5 \mathrm{ml} / \mathrm{s}, \mathrm{p}=0.001)$, MDRD4 $(\mathrm{GFR}<1.5 \mathrm{ml} / \mathrm{s}$ and $>1.5 \mathrm{ml} / \mathrm{s}, \mathrm{p}=0.001)$ and CKD-EPI (GFR $<1.5 \mathrm{ml} / \mathrm{s}$ and $>1.5$ $\mathrm{ml} / \mathrm{s}, \mathrm{p}=0.001$ ).

\section{The 60-69 year age group}

Women

A high degree of correlations was established between prediction equations and $\mathrm{C}_{\mathrm{cr}}$ (MDRD4 $-\mathrm{r}=0.7790$; CKD-EPI $-r=0.7780$ ), while the CG formula had a moderate degree of correlation $(r=0.6550)$. The curves of moving average show that prediction equation error up to $1.5 \mathrm{ml} / \mathrm{s}$ was at a low level, with a sharp tendency to increase above this value.

Significant differences were detected for prediction equation error for CG (GFR $<1.5 \mathrm{ml} / \mathrm{s}$ and $>1.5 \mathrm{ml} / \mathrm{s}, \mathrm{p}=0.001)$, MDRD4 $(\mathrm{GFR}<1.5 \mathrm{ml} / \mathrm{s}$ and $>1.5 \mathrm{ml} / \mathrm{s}, \mathrm{p}=0.001)$ and CKD-EPI (GFR $<1.5 \mathrm{ml} / \mathrm{s}$ and $>1.5 \mathrm{ml} / \mathrm{s}, \mathrm{p}=0.001$ ).

Men

Correlation analysis of prediction equations and $\mathrm{C}_{\mathrm{cr}}$ revealed a high degree of correlation for MDRD4 $(r=0.8009)$ and CKDEPI $(r=8.0020)$ and a moderate degree for CG $(r=0.5776)$. The chart of moving average showing prediction equation error had a sharply increasing tendency from 0.2 to $0.4 \mathrm{ml} / \mathrm{s}$ and sharply declined from 0.4 to $0.6 \mathrm{ml} / \mathrm{s}$. There was a low error level from 0.6 to $1.5 \mathrm{ml} / \mathrm{s}$ and then a slightly increasing tendency again from $1.5 \mathrm{ml} / \mathrm{s}$. While significant differences were noted in prediction equation error for MDRD4 (GFR $<1.5 \mathrm{ml} / \mathrm{s}$ and $>1.5 \mathrm{ml} / \mathrm{s}$, $\mathrm{p}=0.05)$ and CKD-EPI (GFR $<1.5 \mathrm{ml} / \mathrm{s}$ and $>1.5 \mathrm{ml} / \mathrm{s}, \mathrm{p}=0.001)$, no significant difference was established for prediction equation CG $($ GFR $<1.5 \mathrm{ml} / \mathrm{s}$ and $>1.5 \mathrm{ml} / \mathrm{s})$.

\section{The 70-79 year age group}

Women

A moderate degree of correlation between all prediction equations and $\mathrm{C}_{\mathrm{cr}}$ was found in this female group (MDRD4 $r=0.6730$; CKD-EPI $-r=0.6650$; CG $-r=0.5400$ ). From the moving average, we detected a low level of prediction equation error to $1.5 \mathrm{ml} / \mathrm{s}$, with a sharply increasing tendency above this value. Significant differences between prediction equation error were established for CG (GFR $<1.5 \mathrm{ml} / \mathrm{s}$ and $>1.5 \mathrm{ml} / \mathrm{s}, \mathrm{p}=0.01$ ),
MDRD4 (GFR < $1.5 \mathrm{ml} / \mathrm{s}$ and $>1.5 \mathrm{ml} / \mathrm{s}, \mathrm{p}=0.001)$ and CKD-EPI $(\mathrm{GFR}<1.5 \mathrm{ml} / \mathrm{s}$ and $>1.5 \mathrm{ml} / \mathrm{s}, \mathrm{p}=0.001)$.

Men

Moderate correlation was detected between all prediction equations and $\mathrm{C}_{\mathrm{cr}}(\mathrm{CG}-\mathrm{r}=0.6381$; CKD-EPI $-\mathrm{r}=0.6277$; MDRD4 $-r=0.6154)$. The chart of moving average showed sharply declining prediction equation error to $0.4 \mathrm{ml} / \mathrm{s}$ followed by a low error level from 0.4 to $1.2 \mathrm{ml} / \mathrm{s}$, then sharply increasing tendency between 1.2 and 1.8 and finally slightly declining above this value. Significant differences were registered for prediction equation error for CG $(\mathrm{GFR}<1.5 \mathrm{ml} / \mathrm{s}$ and $>1.5 \mathrm{ml} / \mathrm{s}, \mathrm{p}=0.01)$, MDRD4 (GFR $<1.5 \mathrm{ml} / \mathrm{s}$ and $>1.5 \mathrm{ml} / \mathrm{s}, \mathrm{p}=0.05$ ) and for CKDEPI $($ GFR $<1.5 \mathrm{ml} / \mathrm{s}$ and $>1.5 \mathrm{ml} / \mathrm{s}, \mathrm{p}=0.05)$.

\section{DISCUSSION}

The most common problem in $\mathrm{C}_{\mathrm{cr}}$ estimation remains centred on inaccurate 24 hour urine collection reports, and factors interfering with 24-hour urine accuracy cannot be offset by current analytical methods $(14,15)$. The accuracy of most delivered diuresis in our study was limited to levels of 1 litre, 0.5 litre or 100 $\mathrm{ml}$, with a small number of measurements accurate at the $10 \mathrm{ml}$ level. This caused suspicion concerning participants' subjective estimation, rather than precise measurement.

This study yielded information on GFR estimation by $\mathrm{C}_{\mathrm{cr}}$, with the aim to use prediction equations CG, MDRD4 and CKD-EPI to estimate GFR levels from $\mathrm{S}_{\mathrm{cr}}$. Many studies have estimated clearance of inulin $\left(\mathrm{C}_{\text {in }}\right)$ level and compared obtained values with eGFR estimation by prediction equations $(16,17)$. Other studies estimated GFR by creatinine and cystatin C and found that adjustments to both parameters were comparable (18, 19). In our study, we compared $C_{c r}$ estimation with prediction equations; because $\mathrm{C}_{\text {in }}$ estimation is complicated in continuous inulin intravenous administration and adjustment by cystatin $\mathrm{C}$ is more expensive $(6,18) . S_{\mathrm{cr}}$ is a good indicator of renal function, but the conclusion of authors is that $S_{c r}$ values are affected by factors including age, diet, muscle mass, and drugs, therefore, they should not be used as a standard in GFR determination (20-22). More recently, calculation of eGFR by empirical mathematical formulae, such as CG, MDRD and CKD-EPI, has been encouraged as a simple, rapid and reliable means of assessing kidney function.

Herein, correlation analysis produced the best correlations between $\mathrm{C}_{\mathrm{cr}}$ and the MDRD4 prediction equation for women $(\mathrm{r}=0.7790)$ and men $(\mathrm{r}=0.8009)$, and between $\mathrm{C}_{\mathrm{cr}}$ and CKD-EPI for women $(r=0.7780)$ and men $(r=0.8002)$ in the 60-69 year age group. We found a high correlation between $\mathrm{C}_{\mathrm{cr}}$ and the CG $(r=0.8655)$ and MDRD4 $(r=0.8713)$ prediction equations for men in the 40-49 year age group. High correlation between $C G$; MDRD4 prediction equations and $\mathrm{C}_{\mathrm{cr}}$ was reported in an adult Japanese population by Aizawa et al. (23). Egi et al. (24) and Botev et al. (17) registered similarly high correlations between Cin and CG and MDRD4 prediction equations for subjects aged $46 \pm 16$ years. In addition, our study also confirms the finding between $\mathrm{C}_{\mathrm{cr}}$, CG and MDRD4 prediction equations for men, and this suggests advantageous use of the MDRD4 and CKDEPI formulae for men in the 60-69 age range. Our study is also consistent with the study of Zitta et al. (25), which concluded 
that for routine purposes in cases of poor renal function eGFR methods are generally reliable.

Conclusions drawn by Schück et al. and Soares et al. (26, 27) as well as the results of our study show that prediction equations for determining GFR are not universally applicable for all patients, because equation accuracy improves in healthy populations without kidney disease. Age variation is also an important parameter because creatinine production experiences physiological decline with increasing age, so age becomes very important in $\mathrm{C}_{\mathrm{cr}}$ regulation $(28,29)$. Since the Pearson coefficient of correlation did not provide adequate comparison of $\mathrm{C}_{\mathrm{cr}}$ and prediction equations (30), our methodology was altered to comparison of prediction equation errors and comparison of significant differences between the three formulae for individual age ranges and gender, using GFR $<1.5$ $\mathrm{ml} / \mathrm{s}$ and $>1.5 \mathrm{ml} / \mathrm{s}$ in accordance with the NKF protocol. Despite using different formulae for men and women, and working with different levels of plasma creatinine and/or different aged groups (31), which further complicated this research, we were rewarded with greater accuracy.

Results of the moving average and significant differences in eGFR calculated by prediction equations in the interval GFR $<1.5 \mathrm{ml} / \mathrm{s}$ and GFR $>1.5 \mathrm{ml} / \mathrm{s}$ showed that the utility of prediction equations increased when GFR was $<1.5 \mathrm{ml} / \mathrm{s}$ for each age range, compared to GFR $>1.5 \mathrm{ml} / \mathrm{s}$. An exception was noted for the 30-39 year age group in both genders, where the small number of female $(\mathrm{n}=19)$ and male $(\mathrm{n}=10)$ participants limited our results.

According to both Levey et al. (3) and Michels et al. (32), the CKD-EPI prediction equation is more accurate than the MDRD4 formula. These authors advised the use of CKD-EPI equation for patients with impaired renal function in order to reduce the number of false positive diagnoses to less than $1 \mathrm{ml} / \mathrm{s} / 1.73 \mathrm{~m}^{2}$. The prediction equations have proven advantageous in Chronic Kidney Disease stages $2-5$ in NFK classification (30).

In summary, we contend that the prediction equations afford "first step" diagnosis in the following situations: MDRD4 and CKD-EPI for both genders in the 60-69 age group; and MDRD4 and CG for men in the 40-49 age group.

According to our results, we advise the incorporation of prediction equations as an additional examination of GFR. This will facilitate improvement and validation of kidney examinations in clinical practice in Slovakia regardless of patient age and gender.

\section{CONCLUSIONS}

Based on our statistical analysis of correlation, moving average and comparison of prediction equations in the GFR $>1.5$, GFR < 1.5 interval, the following recommendations are highlighted to improve outcomes for nephrology patients:

1) Inclusion of prediction equations in clinical practice for the currently used $\mathrm{C}_{\mathrm{cr}}$; namely, the MDRD4 and CG equations for men aged 40-49 years, and the MDRD4 and CKD-EPI equations for both men and women aged 60-69 years;

2) The incorporation of these three prediction equations in clinical practice in Slovakia to form additional examination of $\mathrm{C}_{\mathrm{cr}}$ for the gender and age groups not included in the previous sentence but examined in the Results section of this paper.

\section{Acknowledgement}

The authors wish to thank the Laboratory of Clinical Biochemistry in Partizánske Hospital for their technical assistance during conduction of these experiments.

\section{REFERENCES}

1. Pasminka T. Chronic kidney disease: epidemiology, classification and screening. Via Practica. 2005;2(10):398-9. (In Slovak.)

2. McGeown JG. Physiology: a core text with self-assessment. 2nd ed. Edinburgh: Churchill Livingstone; 2002.

3. Levey AS, Stevens LA, Schmid CH, Zhang YL, Castro AF 3rd, Feldman HI, et al.; CKD-EPI (Chronic Kidney Disease Epidemiology Collaboration). A new equation to estimate glomerular filtration rate. Ann Intern Med. 2009 May 5;150(9):604-12.

4. Kasiske BL, Keane WF. Laboratory assessment of renal disease: clearance, urinanalysis, and renal biopsy. In: Brenner BM, editor. Brenner \& Rector's the kidney. 5th ed. Philadelphia: Saunders; 1996. p. 1137-74.

5. Stevens LA, Coresh J, Greene T, Levey AS. Assessing kidney function - measured and estimated glomerular filtration rate. N Engl J Med. 2006 Jun 8;354(23):2473-83.

6. Johnson LR, Byrne JH, editors. Essential medical physiology. 3rd ed. Amsterdam: Elsevier Academic Press; 2003.

7. Hermida-Cadahia EF, Lampon N, Tutor JC. Impact of creatinine production on the agreement between glomerular filtration rate estimates using cystatin C-derived, and 4- and 6-variable Modification of Diet in Renal Disease (MDRD), and Chronic Kidney Disease Epidemiology Collaboration (CKD-EPI) equations. Ups J Med Sci. 2012 Nov;117(4):402-10.

8. Kaplan LA, Pesce AJ, Kazmierczak SC. Clinical chemistry: theory, analysis, and correlation. 3rd ed. St. Louis: Mosby; 1996.

9. Sobh MA. Essentials of clinical nephrology. Cairo: Dar El Shorouk; 2000.

10. Stein A, Wild J, Auer J. Kidney dialysis and transplants: the 'at your fingertips' guide. London: Class; 2002.

11. Earley A, Miskulin D, Lamb EJ, Levey AS, Uhlig K. Estimating equations for glomerular filtration rate in the era of creatinine standardization: a systematic review. Ann Intern Med. 2012 Jun 5;156(11):785-95.

12. Cockcroft DW, Gault MH. Prediction of creatinine clearance from serum creatinine. Nephron. 1976;16(1):31-41.

13. Levey AS, Bosch JP, Lewis JB, Greene T, Rogers N, Roth D; Modification of Diet in Renal Disease Study Group. A more accurate method to estimate glomerular filtration rate from serum creatinine: a new prediction equation. Ann Intern Med. 1999 Mar 16;130(6):461-70.

14. Kubáč $P$, Buryška J. Experience with diagnosis of renal function in Ostrava City Hospital. FONS. 2007;(2):31-7. (In Czech.)

15. Eastwood JB, Kerry SM, Plange-Rhule J, Micah FB, Antwi S, Boa FG, et al. Assessment of GFR by four methods in adults in Ashanti, Ghana: the need for an eGFR equation for lean African populations. Nephrol Dial Transplant. 2010 Jul;25(7):2178-87.

16. Sterner G, Frennby B, Mansson S, Nyman U, Van Westen D, Almén T. Determining 'true' glomerular filtration rate in healthy adults using infusion of inulin and comparing it with values obtained using other clearance techniques or prediction equations. Scand J Urol Nephrol. 2008;42(3):278-85.

17. Botev R, Mallié JP, Couchoud C, Schück O, Fauvel JP, Wetzels JF, et al. Estimating glomerular filtration rate: Cockcroft-Gault and Modification of Diet in Renal Disease formulas compared to renal inulin clearance. Clin J Am Soc Nephrol. 2009 May;4(5):899-906.

18. Tidman M, Sjöström P, Jones I. A Comparison of GFR estimating formulae based upon s-cystatin $\mathrm{C}$ and s-creatinine and a combination of the two. Nephrol Dial Transplant. 2008 Jan;23(1):154-60.

19. Eriksen BO, Mathisen UD, Melsom T, Ingebretsen OC, Jenssen TG, Njølstad I, et al. Cystatin C is not a better estimator of GFR than plasma creatinine in the general population. Kidney Int. 2010 Dec;78(12):130511.

20. Perrone RD, Madias NE, Levey AS. Serum creatinine as an index of renal function: new insights into old concepts. Clin Chem. 1992 Oct;38(10):1933-53.

21. Oo C, Liu B, Hill G. Change in creatinine clearance with advancing age. J Am Geriatr Soc. 2002 Sep;50(9):1603-4.

22. Pohanka E. Of topical interest: stepchild creatinine clearance. Journal für Mineralstoffwechsel. 2007;14(4):198-9. (In German.) 
23. Aizawa M, Hayashi K, Shimaoka T, Yamaji K, Horikoshi S, Tomino Y. Comparison of prediction equations of glomerular filtration rate in Japanese adults. Nippon Jinzo Gakkai Shi. 2006; 48(2): 62-6. (In Japanese.)

24. Egi A, Fukuda H, Kawamoto M, Yuge O. Preoperative prediction of creatinine clearance by using serum creatinine. Masui. 2004 Nov;53(11):130610. (In Japanese.)

25. Zitta S, Schrabmair W, Reibnegger G, Meinitzer A, Wagner D, Estelberger W, et al. Glomerular filtration rate (GFR) determination via individual kinetics of the inulin-like polyfructosan sinistrin versus creatininebased population-derived regression formulae. BMC Nephrol. 2013 Jul 22;14:159.

26. Schück O, Teplan V, Smrčková I, Stávek P, Skibová J, Štollová M. The table facilitating prediction of the glomerular filtration rate on the basis of the MDRD equation (without resorting to a computer program). Prakt Lek. 2004;84(5):271-3. (In Czech.)

27. Soares AA, Eyff TF, Campani RB, Ritter L, Camargo JL, Silveiro SP. Glomerular filtration rate measurement and prediction equations. Clin Chem Lab Med. 2009;47(9):1023-32.
28. Douville P, Martel AR, Talbot J, Desmeules S, Langlois S, Agharazii M. Impact of age on glomerular filtration estimates. Nephrol Dial Transplant. 2009 Jan;24(1):97-103.

29. Glassock RJ, Winearls C. Ageing and the glomerular filtration rate: truths and consequences. Trans Am Clin Climatol Assoc. 2009;120:419-28.

30. National Kidney Foundation. K/DOQI clinical practice guidelines for chronic kidney disease: evaluation, classification, and stratification. Am J Kidney Dis. 2002 Feb;39(2 Suppl 1):S1-266.

31. Diamandopoulos A, Goudas P, Arvanitis A. Comparison of estimated creatinine clearance among five formulae (Cockroft-Gault, Jelliffe, Sanaka, simplified 4-variable MDRD and DAF) and the 24hours-urine-collection creatinine clearance. Hippokratia. 2010 Apr;14(2):98-104.

32. Michels WM, Grootendorst DC, Verduijn M, Elliott EG, Dekker FW, Krediet RT. Performance of the Cockcroft-Gault, MDRD, and new CKD-EPI formulas in relation to GFR, age, and body size. Clin J Am Soc Nephrol. 2010 Jun;5(6):1003-9.

Received December 19, 2012 Accepted in revised form January 16, 2014 